\title{
The Irony of Michael Novak
}

\section{Niebuhr, Democratic Capitalism, and Climate Change}

\author{
Menno R. Kamminga \\ Department of International Relations and International Organization, \\ University of Groningen, Groningen, The Netherlands \\ m.r.kamminga@rug.nl
}

\begin{abstract}
The late influential American intellectual Michael Novak was a self-declared devotee of Reinhold Niebuhr, arguably the foremost twentieth-century American theologian. Novak's The Spirit of Democratic Capitalism (1982) was an attempt to fill the political-economic lacuna in Niebuhr's thought. The present article offers a Niebuhrian irony-focused response to Novak's democratic capitalism in view of climate change as probably the greatest threat facing humanity. Novak quite successfully extended Niebuhrian ideas into a theology-based vision of democratic capitalism as the only political-economic system effective in widely lifting people out of poverty. Yet he failed to acknowledge human-induced climate change as beyond reasonable doubt and rooted in the predominantly American invention of a fossil energy-based capitalist political economy. This article's thesis is that Novak's democratic capitalism entails Niebuhrian irony: the virtue it displays about resources becomes a vice due to Novak's irresponsible post-Spirit of Democratic Capitalism attempt to represent democratic capitalism as innocent of any dangerous climate-change implications.
\end{abstract}

\section{Keywords}

climate change - democratic capitalism - irony - Reinhold Niebuhr - Michael Novak - resources 
The late American Roman Catholic theologian Michael Novak (1933-2017) was a courageous Christian intellectual and writer of enormous public and political influence. As such, Novak roughly resembled his Protestant intellectual role model Reinhold Niebuhr (1892-1971), who is usually regarded as the chief American theologian of the twentieth century. A self-professed follower of Niebuhr since his Harvard student years, Novak (2013, 34-37, 57, 118; cf. 1972; 1977) developed a strong interest in Niebuhr's Christian realism and steadfastly praised the latter's attention to irony, realism, balance of power, experience, and unintended consequences. Yet, observing that Niebuhr had not written extensively on political economy, Novak decided to make that the heart of his career: "Precisely in Niebuhr's neglect I found my own vocation" (1992, 40). Thus, Novak's masterpiece (Eberstadt 2019; Steinfels 2017) on political economy, The Spirit of Democratic Capitalism, published in 1982, devotes a full chapter to Niebuhr alone (Novak 1991a, 315-332). ${ }^{1}$ As Novak (1991a, 314) explains:

To have learned from [Niebuhr] is to have had a wise man for a teacher - and to find in his reflections on politics a model for reflection on economics. Work in such a complex field always requires learning much from others, so it seems useful to walk in Niebuhr's shoes before attempting to press beyond.

In this influential_ - albeit controversial_ book, Novak argues that democratic capitalism - a caput-driven (i.e., mind-driven) market economy molded by a pluralist moral culture and democratic political system-is humanity's only real chance for sustained prosperity in a world normally characterized by poverty. Translated into many languages, read secretly by dissident movements, and highly inspirational toward and after the end of the Cold War, The Spirit of Democratic Capitalism made Novak the "theologian of capitalism." Novak's underlying journey from liberal progressivism to realist conservatism cost him many relationships with old friends from the left-somewhat like what Niebuhr had experienced with former fellow pacifists, finding himself alienated from the US Socialist Party in 1940 for his defense of American military intervention in Europe.

How to assess the intellectual legacy of this recently deceased, Niebuhrinspired Catholic theologian, public intellectual, adviser to popes, and prolific

$1 \quad$ All references to The Spirit of Democratic Capitalism in this article are to the 1991 edition. 
author, who defended the spirit of a now global capitalist system? The present article's contribution is a sympathetic yet critical Niebuhrian response to Novak's democratic capitalism in the light of climate change as arguably the greatest threat now facing humanity. As we shall see shortly, Novak's extension of Niebuhrian thought into a theology-based vision of democratic capitalism was legitimate, if not simply successful. However, as a neoconservative, Novak $(1994,2005,2017)$ ended up not acknowledging the reality and grave dangers of human-induced global climate change. Surely Novak could have learned about climate change from the late 1980s, particularly the ever-increasing certainty that it is caused primarily by carbon dioxide emissions from burning fossil resources, with the typically democratic-capitalist United States (Novak 1991a, 14) as the world's biggest emitter historically (albeit that since 2006 China has taken the lead). Thus, even if Novak was right that capitalism is the only economic system effective in lifting people out of poverty on a large scale, he should have come to terms with the fact that this American-invented, fossil energy-based political economy in its global application has greatly contributed to climate change.

For my assessment of Novak's political-economic thought I shall draw on Niebuhr's The Irony of American History, first published in 1952, which, in Andrew Bacevich's words, "is the most important book ever written on U.S. foreign policy" (Bacevich, in Niebuhr 2008, ix). From his Christian perspective, rooted in the biblical view of human freedom, Niebuhr chose irony-as opposed to pathos and tragedy - as the concept with which to interpret the modern world, particularly postwar US foreign policy. As he wrote (Niebuhr 2008, xxiv):

If virtue becomes vice through some hidden defect in the virtue; if strength becomes weakness because of the vanity to which strength may prompt the mighty man or nation; if security is transmuted into insecurity because too much reliance is placed upon it; if wisdom becomes folly because it does not know its own limits—in all such cases the situation is ironic.

An ironic situation, Niebuhr explained, differs from a pathetic one in that "the person involved in it bears some responsibility for it" and from a tragic one in that "the responsibility is related to an unconscious weakness rather than to a conscious resolution" (2008, xxiv). Niebuhr, then, argued that the American condition, like the opposite Soviet one, is ironic: "Our modern liberal [American] culture ... is involved in many ironic refutations of its original pretensions of virtue, wisdom, and power" (2008, xxiv); "our dreams 
of a pure virtue are dissolved in a situation in which it is possible to exercise the virtue of [international] responsibility ... only by courting the prospective guilt of the atomic bomb" $(2008,2)$. Niebuhr felt that Americans-finite and sinful human beings like anyone else-wrongly cultivated a self-image of pure innocence by denying all moral cloudiness of their great-power global leadership, which was the unintended outcome of their efficacious isolationist attempt to flourish without global responsibilities. Thus, Niebuhr's irony signaled the Americans' capacity for evil in their new power position and identified their corresponding obligation to repent and take responsibility, even if they had not particularly sought that position. The irony was increased by a pervasive idealism that, by oscillating between power-forsaking noninterventionism and power-glorifying imperialism, only undermined security.

Why, more specifically, employ Niebuhrian irony for the purpose of a climate change-oriented reading of Novak's democratic capitalism? First, Novak often invoked Niebuhrian irony throughout his work; he even found it "surprising that Catholic moralists have not made as fertile use of the classic concept of irony as Niebuhr has," as it is "a matter of common experience that human actions nearly always have unintended consequences, which often sharply contrast with best intentions" (Novak and Adams 2015, 189). Thus, drawing on Niebuhrian irony could help us assess Novak's democratic-capitalist view on its own terms.

Second, Niebuhr $(2008,7,112-115,120)$, who could not have known about climate change, showed an irony-relevant awareness of environmental problems caused by economic materialism. Niebuhr noted a human inclination to abuse nature beyond meeting "human needs" toward satisfying "human wants" (1932, 1). Favoring humility and modesty, he lamented how "American culture [of] constantly expanding production" had made "living standards' the final norm of the good life" (Niebuhr 2008, 57; cf. Lieven 2010, 174). This, Niebuhr $(2008,43-64)$ felt, threatened to violate limits that should be respected. To quote him:

The prosperity of America is legendary. Our standards of living are beyond the dreams of avarice of most of the world. We are a kind of paradise of domestic security and wealth. But we face the ironic situation that the same technical efficiency which provided our comforts has also placed us at the center of the tragic developments in world events. There are evidently limits to the achievements of science; and there are irresolvable contradictions both between prosperity and virtue, and between happiness and the "good life" which had not been anticipated in our philosophy.

NIEBUHR 2008, 45 
Third, then, had he lived, Niebuhr might have diagnosed climate change and its threat to human security as a key example of irony, that is, as an ironic result of humanity's most effective attempt to transform poverty into prosperity. Thus, the same power that freed Americans (and others) from natural threats has involved them in new threats. While Americans have not sought any planet-endangering power, they should assume responsibility for the unintended deleterious environmental consequences of their wellintentioned, hope- and ideals-driven efforts toward American and global welfare achievement. Climate change might even be the ultimate irony of American history in which China, India, and developing countries have come to figure as big polluters due to a global spread of fossil-fuel dependence and consumerism; arguably, this outcome is beyond pathos or tragedy but related to a rather blind pride about the American way of life (Barr and Sabella 2017; Kamminga 2018; Lieven 2010). ${ }^{2}$

My main thesis here is that Novak's democratic capitalism entails a core Niebuhrian irony: the virtue it does display about resources (notably against socialists or egalitarians) eventually turns into a vice due to Novak's irresponsible post-Spirit of Democratic Capitalism attempt to represent democratic capitalism as innocent of any dangerous climate-change implications. ${ }^{3}$ Thus, ironically, Novak himself undermined the moral integrity of his democratic capitalism by locking it up into a (what I call) conservative idealism that precluded the acceptance of any democratic-capitalist responsibility for global

2 Since Niebuhr's irony is related to the basic Christian doctrine of original sin, a reviewer wondered why I do not directly employ the term original sin rather than irony. As the reviewer put it, due to a fundamentally flawed human nature, good intentions go awry and potentially good social systems end up in a mess. However, for my purpose of critical interpretation, the concept of irony is much more fruitful than the concept of original sin. Irony has greater operationalizability and, accordingly, more potential to yield more immediately interesting knowledge; it has the force to highlight both positive and negative features and the relationship between these in a specific context. By contrast, original sin more generally refers to a universal human condition which, besides good intentions gone wrong, more broadly also includes bad or evil intentions and pure evil, with which I will not be concerned. As Niebuhr (2008, xxiv, 17) put it, irony is a "principle for interpretation"; original sin states an "obvious fact." That said, the notion of sin will return several times in this article.

3 Niebuhr (2008, xxiv), as we saw, distinguished four possible irony-identifying conceptual pairs: virtue-vice, strength-weakness, security-insecurity, and wisdom-folly. I submit that much of this conceptual terminology can be discerned in Novak's irony, which adds to its seriousness. Yet I use the conceptual pair virtue-vice as a shorthand, not only for the sake of readability but also because Niebuhr (2008) mentioned this pair first, seemed to have a special preference for it, and did not bother to create any sharp distinctions between the pairs. 
climate change. Novak, then, did not listen well enough to his intellectual teacher when he aimed to develop a "Niebuhr-proof" vision of a free and democratic-capitalist political economy as a model for the world. ${ }^{4}$

Before continuing, I should clarify that applying the framework of Niebuhrian irony will not yield hard evidence. As Niebuhr (2008, xxiv-xxv, 151-152) himself acknowledged, the use of the irony concept for the purpose of interpretation should lead one to develop a nonarbitrary and fruitful, enlightening understanding, but it cannot generate factual and judgmental accuracy. Thus, while I submit that my assessment of Novak and his democratic capitalism is plausible, I should also offer it with due modesty.

\section{The Niebuhrian Validity of Novak's Democratic Capitalism}

Why may we say that Novak successfully, or at least legitimately, extended Niebuhr's thought into an economic theology of democratic capitalism? Why, in other words, is Novak's democratic capitalism to be taken seriously from a Niebuhrian perspective? I offer three reasons. ${ }^{5}$

4 Against one reviewer, I maintain that this article is no fallacious ad hominem attack on Novak. I do address the relationship between the author Novak and his work as regards democratic capitalism, as this relationship is one major substantive issue when we try to assess his theological-political-economic legacy. However, we should not doubt the honesty of Novak's own character and motives (nor his capacity for judgement). Critics and friends remember Novak as sincere, unselfish, and truly concerned about economic opportunities for real, ordinary, poor people (Steinfels 2017; Pakaluk 2017). Such was also my own impression when I met Novak at the 1991 Lancaster conference "Religion and the Resurgence of Capitalism," where he kindly signed my copy of The Spirit of Democratic Capitalism and generously answered my questions. Moreover, Niebuhr's irony-based method of critical interpretation allows me to assess Novak's intellectual legacy from a sympathetic starting point, one that may appreciate intellectual virtue, good intentions, and a genuine concern for the poor. Subsequently, to identify a democratic-capitalism-climate-change problem in his work, and to argue that he did not address that responsibly, is not to invalidate the originally assumed good intentions. To acquire a Niebuhrian-irony understanding of Novak's failure in this regard surely entails criticizing him, but legitimately so for particular intellectual choices he made as regards relevant ideas to uphold and their qualitative impact on his democratic capitalism. Finally, to argue that Novak's democratic capitalism entails a key irony also does not imply an attack in the sense that it should be labeled "pure evil" (Niebuhr 2008, xxiv) or that other views should be assumed to be free from irony. Niebuhr (2008) himself saw irony in both communism and (American) liberalism, yet he regarded communism as more dangerously evil at the time. "Irony," Niebuhr explained, prompts a "laughter" that expresses "mercy as well as judgment" (2008, 64).

5 In response to a reviewer, I stress that this section cannot discuss the intra-Catholic Novak debate and (roughly) show Novak's invulnerability to criticism from fellow-Catholic sources. 
First, having always been troubled by injustice, Niebuhr would probably have applauded Novak's focus on helping the poor-without glorifying them as being beyond sin, interest, and vice (Niebuhr 1932, 160; 2008, 163-165; Novak 1991a, 331, 332, 410)—as basic constant in the latter's career and thus also as "[lying] at the heart of The Spirit of Democratic Capitalism" (Eberstadt 2019). Thus, Niebuhr should have had no fundamental reason for rejecting Novak's conclusion that the only realistic way to lift the poor out of poverty is the possibility for them to creatively build businesses that help them participate in economic growth within the context of a free and democratic society. After all, although this may seem counterintuitive, it was primarily for the sake of the poor that Novak felt he should become a conservative who recognized the critical contributions of entrepreneurship, enlightened self-interest, risk, reward, and trust. Hence he held that, to quote his address upon winning the 1994 Templeton Prize, "for all its deficiencies, even gaping inadequacies, capitalism is better for the poor than either of its two great rivals, socialism and the traditional Third World economy. Just watch in which direction the poor of the world invariably migrate" (Novak 1994). ${ }^{6}$

Second, Novak plausibly, even if overenthusiastically, argued that Niebuhr's career had anticipated those of later neoconservatives toward an acceptance of democratic capitalism. During his life, Niebuhr moved from disillusionment with liberal rationalism, via Marx and (democratic) socialism,

Within the context of this article, this section's more limited aim is to demonstrate Novak's justifiable extension of the thought of his intellectual guide Niebuhr into political-economic territory-resulting in democratic capitalism - so that further analysis from a Niebuhrian perspective becomes warranted. By bracketing other issues for the sake of a separate argument that highlights a neglected problem in the debate about Novak's thought, I can sensibly create room for a sympathetic yet critical inquiry that eventually offers one particularly direct and arguably important critique of Novak's treatment of democratic capitalism.

6 A reviewer objected that Novak did not express his concern for the poor by talking with the poor and their organizations themselves, or by referring to early local authors, notably those of Latin America; rather, he uncritically endorsed the "Anglo" arguments of thinkers such as Adam Smith and David Hume, who actually talked over the poor's heads. In response, I note that, when Novak did meet local Latin Americans in Sao Paulo, Brazil, in May 1985, he was greeted with hostility (Novak 1991b, xiv, 237-238, 243-244). Also, as a nonlibertarian Catholic communitarian, Novak (1991a, 419-421) did not wish to endorse such Anglo arguments uncritically. Moreover, arguably the key issue is not with whom one has actually interacted (not to mention the question of whether people, including the poor or their representatives, always know best themselves), but what works best in eventually getting people out of poverty. In this sense, for all its flaws, capitalism arguably has a better track record than any other political-economic system humanity has known thus far. 
to a deeper appreciation of democracy and capitalism. Surely what inspired the conservative Novak was that Niebuhr had consistently been committed to realism, practical wisdom, and an Augustinian anthropology of original sin, the "effect [of which] is to deflate human pretensions of unambiguous virtue" (Novak 1991a, 315, 349). To be sure, Novak's later view that Niebuhr was a "model for neoconservatives" $(1986,69)$ and that "the truest disciples of ... Niebuhr are conservatives" $(1992,40)$ was overstated (cf. Novak 1972). After all, while Niebuhr came to appreciate the free market's contribution to the balance of power within a democratic society, he went on to uphold social progressivism and to distrust laissez-faire (Rice 2015, 77-78). Yet, while well aware that Niebuhr had always belonged to the political left and never clearly exchanged socialism for a reformed capitalism, Novak (1991a, 324; 1986, 71) had a point: Niebuhr did travel toward democratic capitalism and ended up close to a left-wing version of this system. Thus, Niebuhr increasingly saw the pragmatic and moral benefits of a free market and private property rights, albeit within a societal context of balances of power and justice. He also came to praise capitalism's realism about self-interest, which must be both allowed some free play and harnessed for the common good (Novak 1991a, 327-328, cf. 329-330). Remarkably, Niebuhr, an empiricist resilient to utopian (socialist) temptations, eventually referred to the US system by the expression “'capitalist-democratic' culture" $(1965,81)$, which was roughly to become Novak's phrase (cf. Novak 1991a, 328-329).

Third, from a Niebuhrian perspective it is to be positively valued that Novak (1991a, 13, 16, 22, 39, 57, 247, 277, 433) defended capitalism not only against socialism and traditionalism but also against mercantilism, that is, a state-controlled protectionist economy. Mercantilism had long been the dominant system of political economy and had characterized the (colonial) Catholic and Protestant powers of the seventeenth century. However, Novak noted, it was a key obstacle to the development of a welfare economy, which only became possible after the capitalist revolution. Thus, whereas many critics of capitalism have conveniently but confusingly criticized the very different position of (colonialist) mercantilism instead, Novak's capitalist rejection of mercantilism tied in with Niebuhr's explanation of the pervasive egoisms of political-economic groups and his dismissal of national egoism's typical impact as sin and idolatry (Niebuhr 1941, 221-226). Remarkably, a renowned critic of economic globalization such as Thomas Pogge actually offers support to the linking of Novak to Niebuhr by underlining the potential virtues of capitalism as opposed to the vices of contemporary mercantilism. Pogge does not criticize global capitalism as such but offers a focused critique of contemporary West-led global governance within the 
world economy. "Capitalism," Pogge holds, "means [a market economy based on] the private ownership of the means of production"; this framework, if regulated adequately, can be compatible with justice (in Musyal and Eiermann 2011; cf. Pogge 2008, 19, 30). What we should reject for being a key contributor to global poverty, then, is how the rich countries shape world markets by using their power to make (unfair) market rules and impose these on poor countries. What we should not reject are open markets and free trade, as we lack truly successful socialist experiments or other feasible and better alternatives to capitalism (Pogge 2008, 18-19).

I have formulated three reasons for why Novak's democratic capitalism is valuable from a Niebuhrian perspective: basic focus on the poor; consistency with Niebuhr's own intellectual development; and critique of national group egoism. Thus, a closer inquiry of Novak's stance on political economy from the viewpoint of Niebuhrian irony is sensible and worthwhile, especially in view of a clear threat such as global climate change.

\section{Novak's Virtue: Resources as Cultural Gift}

I shall now argue that Novak's democratic capitalism displays a major (and often overlooked) virtue about resources, one that lies in democratic capitalism's cultural-communitarian foundation-ingeniously identified by Novak - of the Industrial Revolution and of fossil energy as having been essential to the creation of welfare in a world in which poverty is common. Their later-discovered climate problems notwithstanding, modern fossil resources-rooted in a Western, notably Anglo-Saxon, cultural history of inventiveness, industriousness, and hard work-have been essential to replacing a millennia-long state of hunger and misery by sustained welfare. Resources (such as fossil and nuclear ones) are more than just matter; without Europe-particularly the English Industrial Revolution (see also Landes 1998) — and the United States with its creative talents and efforts, we might never have come to recognize their value. As we shall see, then, Novak's analysis makes us understand why no good reason exists for endorsing the philosophically popular view that the total available resources and, accordingly, the total available atmospheric room for greenhouse gas emissions should have been globally distributed in some egalitarian way. ${ }^{7}$

Novak (1991a, 305) noted that before the invention of the steam machine and the Industrial Revolution, securing economic development had been

This section draws and builds on Kamminga (2019, 8-10; 2020, 760-763). 
impossible. Through science, technology, and economic organization, England did eventually achieve this first (Novak 1991a, 301):

In 1850, Great Britain was just completing seventy straight years during which, with a dynamism never before matched in history, its gross national product grew every year by an average of nearly 2 percent a year. This seemingly miraculous achievement introduced into the world the reality of economic development.... The law of patents had greatly stimulated invention, as had the Royal Society. In every decade and in almost every year, new technologies excited the populace.

Regarding the United States, Novak observed that left-egalitarians who criticize this country for its disproportionate use of fossil energy do so on crucially mistaken assumptions. In 1970, the Brazilian archbishop Dom Helder Camara stated that "it is a sad fact that 80 percent of the world's resources are at the disposal of 20 percent of the world's inhabitants" (Novak 1991a, 299). Like how "in the 1970s, the lefties used to talk about $6 \%$ of the world's population using $25 \%$ of the world's energy," presidential candidate Barack Obama said about the United States that " $3 \%$ of the world's population ... accounts for $25 \%$ of the greenhouse gases put into the atmosphere" (Novak 2008a). Novak, however, explained that the democratic-capitalist United States has not simply used so much fossil energy, but it has invented the lion's share of modern energy. Thus, "in 18 og an American outside Philadelphia figured out how to ignite anthracite coal. The ability to use anthracite ... made practical the seagoing steamship and the locomotive" (Novak 199o, 44). Moreover:

The word "resources" . . . must . . . be stripped of ideology. . . Q Quite diverse cultural histories lie behind it. The combustion engine was invented under democratic capitalism barely a century ago. The first oil well was dug in Titusville, Pennsylvania, in 1859, and the first oil well in the Middle East was dug only in 1909. If oil is today ... a "resource," one must recall how short a time ago the entire human race lay in ignorance of its potential. Most of the materials we today call resources were not known to be such before the invention of a democratic capitalist political economy.... Dumb material remains inert until its secrets are discovered and a technology for bending it to human purposes is invented. The word "resources," therefore, includes within its meaning the factor of culture, of which discovery and invention are expressions.... In fairness: ... [8090] percent... of the world's resources have been discovered and put to use ... by one of the smaller cultures on the planet. The benefits of 
such discoveries have been carried to every continent, but more must now be done in this direction. ... Some cultures have organized their political economy precisely for [the] purpose [of discovering resources and inventing technologies for using them]. Others have not.

NOVAK 1991a, 299-300

More recently, Novak (2008a) listed various resource-using devices as American creations:

Electricity, the Franklin stove, the steam engine, the piston engine propelled by gasoline (and now by electric and/or hydrogen batteries), the processing of crude oil into gasoline, nuclear energy, the jet engine, the development of ethanol and other fuels derived from plants, and other devices-all of these except one [the British-invented steam engine] were invented by the people of the United States, as their gift to the world.

Actually, Novak overstated the US contribution in relation to the European one (which could be seen as a first sign of his Niebuhrian irony); but perhaps this was offset by his explicit awareness of the fertility of the Protestant European culture (Novak 1991a, 300). Still, although the United States has constantly made technological and commercial-optimizing contributions, underlying these are often originally European inventions (e.g., engines, batteries, and nuclear energy). Nevertheless, the cultural point is clear: nearly 100 percent of modern energy is of Western, largely American, democratic-capitalist origin.

Basically, Novak's insight is communitarian rather than cosmopolitan. Human beings are "communitarian individuals" (Novak 1991a, 143-155), who can be creators within a suitable cultural-institutional context of inventiveness and industriousness. The ideational factor of cultural-historical achievement, without which fossil resources could not have come into existence, makes a decisive difference. Thus, Novak convincingly showed that, since culture is the key factor for resources, an abstract cosmopolitan ethics of (roughly) egalitarian distributive resource justice is beside the point, if not absurd (Novak 1990, 43). That widely held position holds that all human beings have an equal original claim to a share of the total available resources and, by implication, of the total available room for greenhouse gas emission. However, for this it relies on the dubious assumption that resources are naturally distributed and as such exist independently of human beings (Beitz 1999, 139-141; Blomfield 2019; Neumayer 2000; Matthews 2016; cf. Obama [in Novak 2008a], cited above). Therefore, it cannot see Novak's double point of (modern) natural resources 
being human culture dependent: first, they exist as one culture's (or a few cultures') invention, and second — as Novak also explained in the two indented quotations above-they subsequently (could) have been a beneficial gift to other cultures, even if perhaps this gift has not yet been generous enough. ${ }^{8}$

That Novak's communitarian argument possesses Niebuhrian virtue can be clarified further in four ways. First, by showing that cosmopolitan ethical arguments for "fair" principles of resource or emission "justice" are weak for assuming a materialist view of modern resources, Novak's argument is in line with Niebuhr's critique of complete theories that include final principles of justice. Niebuhr (1941, 301; 1943, 256-266) argued that, whereas equality, liberty, and order may have regulative value, all historical principles will be too corrupted by evil to be definitive; indeed, reason itself may be tainted by sin. Within just-war theory as a set of principles, Niebuhr rejected the possibility of making "obvious distinctions between 'justice' and 'injustice" and warned against putting "undue confidence in human reason" (1941, 300, 298). As regards the issue of fairly distributing resources, Novak applied Niebuhrian wisdom by providing good cultural-historical sensibility against overexploiting reason, something that could only generate some inert "exactness."

Second, a major strength of Novak's democratic-capitalist resource culturalism is that it is not typically conservative but may be accepted by leftist communitarians as well. A (roughly) progressive-communitarian philosopher such as John Rawls, although he was a defender of egalitarianism within liberal societies, held that "the causes of the wealth of a people... lie in their political culture and [their] religious, philosophical, and moral traditions ..., as well as in [their] industriousness ... cooperative talents ... and . . capacity for innovation" (1999, 108). Rawls would have agreed that "the greatest source of wealth in Great Britain and the United States ... is not natural resources so much as capacity for organization" (Novak 1977, 29; cf. 1991a, 432).

Third, for all their later-discovered climate flaws, fossil fuel-based innovations have done, and still do, much good for billions of people and, as such, surely are a democratic-capitalist "gift to the world" (Novak 2008a); and we cannot just rule out West-invented nuclear energy as a more climate-friendly alternative. Indeed, to view the technical-industrial development of the last centuries as mere greedy exploitation, as environmentalists often do, is to unwisely disregard the real human benefits it has brought and the genuine role of real people's noble intentions in driving it (Barr, in Barr and Sabella 2017). Justifiably, then, Novak

8 As Novak (1991a, 299) also noted, the members of the Organization of the Petroleum Exporting Countries possess most of the oil and control its supply and price. The West is often a net payer and thus lacks full control of the benefits of its own inventiveness. 
(1991a, 434-437; 2005) warned against the postcommunist, environmentalist anticapitalism.

Fourth, while granting that the (mercantilist) West owes poor countries compensation for economic injustices, Novak (1977, 29-30; 1991a, 272-297) reasonably criticized the leftist idea of the Third World being poor due to capitalist exploitation of its people and resources-like how Niebuhr had protested that "our good fortune is not so simply a proof of our injustice as our Marxist detractors assert" (Niebuhr 2008, 163). As Novak (1977, 30) stated, Niebuhr had noted that "the difference between our wealth and the poverty of the technically undeveloped world is interpreted by communist propaganda as irrefutable evidence of the exploitative character of our economy," and that "according to this ideology, poverty is caused solely by exploitation" (Niebuhr $2008,116,117)$. As Novak $(1977,30)$ also observed, Niebuhr had highlighted "the ironic situation ... that the most powerful and technically the most efficient modern nation is condemned in a court of public opinion, strongly influenced by Marxist dogma, not so much for its real sins as for [its] achievements" (Niebuhr 2008, 118). Novak, then, credibly insisted that poverty was not recent and that Western cultures with their intelligence, inventiveness, and industrialization conferred wealth on other world regions. The prospects for developing countries would probably not have been better without the Western capitalist inventions of industry, medicine, the productive use of oil that had lain unfound and unvalued under Arabia for millennia, merchant ships, and marketing skills (Novak 1977, 29-30; 2014).

Thus, the key virtue of Novak's culturalism is that it highlights something normally ignored by critics who invoke "global (climate-change) justice" to accuse the United States and the West of having used (much) more than their "fair share" of fossil energy: Western democratic capitalism invented the very usefulness of such resources for overcoming the regular state of poverty and creating sustainable welfare, to the (indirect, if not direct) real benefit of people outside the West as well. Thus, in the case of resources at least, plausibility exists for Novak's Catholic — yet Niebuhr-inspired—critique of distribution-based "static justice" as utopian abstract and overlooking sin and power, and for his defense of real "social justice" as grounded in the virtues of individual and communal initiative and responsibility (Novak and Adams 2015).

\section{Novak's Vice and Irony: Rash Climate Blindness}

I shall now argue that Novak's democratic capitalism shows irony, as its above-identified virtue eventually turns into a vice because of Novak's 
irresponsible, ideological rather than theological, post-198os attitude toward climate change. Thus, Novak belittled resource-based and capitalism-induced climate change and thereby ignored its harmful impact on the global poor, whereas his democratic capitalism is supposed to help the poor; and he did so by overidealizing democratic capitalism as model for (or gift to) the world due to his conservative-idealist worldview, within which this human-created political-economic system, if kept free from "big government," is treated as virtually omnipotent, also environmentally.

What, more exactly, did Novak say regarding climate change, and how should we assess his views on the matter? Basically, $\operatorname{Novak}(2015,2017)$ advocated blue environmentalism besides expressing climate-change doubt. Firstly, as regards the latter, Novak (2013, 287-288) paid little serious attention to climate change; rather, he ridiculed the issue. Thus, he did not bother to directly discuss the long-standing evidence as reported by the Intergovernmental Panel on Climate Change (IPCC) (1990, 1995, 2001, 2007, 2014) with ever more certainty since 1990. Consider what Novak stated a quarter of a century ago (Novak 1994; cf. 2008b, 2009, 2010):

Ours is not an age of unbelief. It is an age of arrogant gullibility. Think how many actually believed the romances of fascism and communism. Think how many, today, believe in Global Warming; think how many believe in a coming Ice Age — and think how many believe in both! One thing our intellectual betters never lack is passionate belief.

Surely Novak's portrayal of climate change as a (false) belief was wrong. As evangelical Christian and influential climate scientist Katharine Hayhoe (2019) explains, climate change, with its really serious effects on many poor and vulnerable people worldwide (see extensively Hallegatte et al. 2016), ought not to be framed as some substitute religion or something one could believe in (or not). Due to observations, facts and data, and reasonable understanding, we know that human-induced climate change is happening and affects many people badly (Hayhoe 2019; Garvey 2008). Admittedly, in the early 199os, the existence and impact of climate change, or global warming, were not as certain as they are today. However, troublingly, Novak refused to even listen to climate science then, although the 1992 Rio de Janeiro Earth Summit had already adopted a convention requiring signatories to reduce carbon emissions substantially.

Near the end of his life, when human-induced climate change had become a virtual certainty, Novak wrote critically but dubiously about Pope Francis's climate-change concerns as expressed in the latter's encyclical Laudato si': 
Pope Francis sometimes talks with great certainty about matters he has not been trained to deal with. He sometimes allows close advisers to disparage those who are not intimidated by a highly politicized scientific "consensus." Can there be "science" where there is so much political pressure and public mockery? Is the pope alert to the fact that to put climate control into the hands of a world government is to create a center of enormous power, able to bring on world decline by wildly erroneous miscalculations? ... Climate history is complex, tangled, and not easy to explain: warm, even hot weather (when Greenland was not yet covered with ice), then a thousand-year Ice Age, and then a "global warming" that also does not show up as predicted. Time spans are long and changeable. There have been cosmic forces at play, from giant meteorites to solar explosions. Breakthroughs in science regularly overturn the conventional "consensus," but the conventional wisdom at any one time is seldom questioned. If Francis turns out to be wrong on climate control, his mistake may end as a far greater blow to the Church than the Galileo Affair.

NOVAK 2017, xxvi-Xxvii

Here Novak was seriously wrong. First, he ridiculed the IPCC-based, established worldwide consensus on climate change, one that includes virtually all climate scientists, without supplying direct and concrete counterevidence but overstressing the medieval "greenness" of Greenland instead (cf. Novak 2007). Second, over the last decades, climate change has unfolded as predicted (Hausfather et al. 2020). Basically, many predictions have been proven correct: the earth warms up 0.2 degrees Celsius every decade; many countries face broken highest-temperature records; hurricanes have increasing force and impact; dangerous ice melting happens at the earth's poles. Grounded in observation, climate science entails a clear falsification of Novak's comments that "temperatures have been flat or slightly cooler since 1997" and "for myself (no scientist), I calculate that global cooling is more likely than global warming" (Novak 2009). Third, his critique was unfair to Francis's dealing with his own lack of expertise by consulting renowned experts. Fourth, the politics of climate change are a matter that is different from climate change as a fact. Climate-government skepticism does not justify climate-change skepticism; if Francis is wrong on climate control, he may still be right on climate change. Fifth, Novak ignored the evidence about the impact of humanity's massive, capitalism-induced fossil-fuel use on climate change and thereby on the poor worldwide.

Next, about his blue environmentalism, Novak wrote optimistically (Novak 2015; cf. 2005; 1991a, 435-436): 
Where people are poor, environmental conditions tend to be abysmal; and ... the twentieth century proved ... that the best way to end poverty isn't red — the color of socialism — but blue, the color of liberty, personal initiative, and enterprise. "Blue Environmentalism" is the way we should build on the stunning success of the environmental movement... The first guiding principle of Blue Environmentalism needs to be realism.... The second guiding principle must be liberty [which] entails creating markets in which both positive and negative incentives function well, in the interest of the environment as well as that of individuals. ... The third and final guiding principle is that we must focus on raising up the poor. The world's worst pollution is in the poorest countries; it arises from primitive methods of heating and cooling, inadequate sanitation systems, and other causes rooted explicitly in poverty.... Blue Environmentalism holds that the best way to help the poor rise out of poverty is to recognize the strict relation of the right to private property to the right of personal economic initiative, and to take the necessary political and institutional steps to give these basic rights realistic support in practice.

However, first, Novak's blue environmentalism looks like a clever capitalist trick to encapsulate the environmentalist critique. Indeed, its three principles are not climate specific or environment specific but mere reiterations of basic notions of Novak's democratic capitalism. Second, in focusing on environmental issues that do result from poverty as such, Novak ignored the typicality of climate change as a capitalism-induced danger that has already done environmental and humanitarian harm and makes many of the world's poor poorer still. This silence about environmental damage as caused by industrialization and wealth is intolerable. Since democratic capitalism, through its invention and spread of fossil-fuel use, appears to engender climate change as well as economic prosperity, Novak's defense of it in The Spirit of Democratic Capitalism has eventually turned out to fall short, and his subsequent blue environmentalism fails as an attempt to rescue it and restate it as environment-friendly solution to poverty. ${ }^{9}$

9 A reviewer objected that it may not be philosophically sound to assume human-induced climate change for the purpose of critique, when there are still credible academics and journalists who dispute the causal role of human agency. So, this reviewer asked, why criticize Novak for rejecting "contemporary scientific narratives about climate change" when "the research is ongoing"? Yet this objection fails; it would be wholly irresponsible for philosophers (among others) to doubt, rather than accept, climate science. First, by now the consensus 
To see, then, why Novak's climate and environmental vice entails a striking case of Niebuhrian irony, we need, in Niebuhrian idiom, to reveal some hidden defect in Novak's position and to show thereby that this position entails nonpathetic and nontragic responsibility as linked to an unconscious weakness rather than a conscious resolution. ${ }^{10}$ Plausibly, Hayhoe (2019) suggests fear as root of climate-change denial: "fear of loss of our way of life, fear of being told that our habits are bad for society, fear of changes that will leave us worse off." Perhaps, then, Novak feared that a human-induced climate change would be a deadly blow to the moral-theological integrity of his democratic-capitalist life project. Another fear Novak may well have had is that climate science, by leading to more government intervention to "make" society, if not to global socialist governance, could jeopardize democratic capitalism's political-economic viability. At any rate, we should regard Novak's fears of climate change and his stress on blue-environmentalist capitalism as basically ideological rather than psychological. As Jean-Daniel Collomb (2014) shows, climate-change denial in the United States "stems from the strong ideological commitment of small-government conservatives and libertarians to laisser-faire and their strong opposition to regulation" and frequent "defense of the American way of life, defined by high consumption and ever-expanding material prosperity." Collomb mentions the neoconservative American Enterprise Institute - the organization Novak worked for in the period 1978 2010-as one leading think tank in the climate-change denial movement. Such fears and convictions suggest Novak's attitude to be an unconscious weakness

among research scientists on anthropogenic global warming has reached 1oo percent, based on a review of 11,602 peer-reviewed articles on climate change and global warming published in the first seven months of 2019; comparably measured, it was already 97-100 percent up until the years 2004 and 2013 (Powell 2019). About this remarkable scientific consensus and the total absence of scientific debate, see also Garvey $(2008,12-17)$ and, in detail, the "Fallacy Man" post: https://thelogicofscience.com/2020/o1/20/the-overwhelming-consensuson-climate-change/amp/. Second, the problem here is that Novak was consistently ignoring, even mocking, the increasingly strong evidence for human-induced climate change, when that had clear relevance for his democratic-capitalist project already during his lifetime. Third, even if, totally unexpectedly and luckily, at some point in the future human-induced climate change turned out to be a complete error, Novak's treatment would not become more justified; without full certainty about climate change, one should still apply a precautionary principle and follow the available massive evidence and current vast scientific consensus. Thus, that Novak did not theorize the intellectual and moral significance of anthropogenic climate change for his democratic capitalism remains unfortunate.

10 Following up on footnote 3, I use hidden defect - which Niebuhr mentions as cause of virtue becoming vice - as a shorthand. It may also refer to the related notions of vanity, overreliance, and self-overestimation. 
rather than a conscious resolution, and thus one he bore responsibility for. Neither pathos nor tragedy help us to grasp Novak's looking away.

Now, to continue our critical interpretation through Niebuhr's conceptual lens of irony: the hidden defect that makes Novak's democratic capitalism ironic is his arguably rather blind, dubious conservative-idealist belief in American and Western democratic-capitalist innocence. This un-Niebuhrianness is shown by, first, Novak's refusal to ask (publicly) what, if human-induced climate change did exist, that would mean for his democratic-capitalist political-economic philosophy and, second, his (blue-environmentalist) suggestion that democratic capitalism cannot pose any dangers to global ecological limits but must be the antipoverty panacea for ecological as well as societal evils. In fact, Novak already burdened his democratic capitalism with a non-Niebuhrian hubris when he called Archbishop Camara's 1970 observation about resources, quoted earlier, "merely a truism," adding the quite pretentious quasi-theological remark that "those cultures which value the intelligent and inventive use of God's creation are far better off than those which do not" (Novak 1991a, 300). Yet, while the ideational invention of resources has proven ecologically bounded due to the still also inescapably material nature of fossil fuels, Novak's capitalist resource idealism exemplifies an overconfidence in the potential of human creators when these are also creatures (cf. Niebuhr $2008,156,158)$. Fixated on human spirit and technological innovation as core solutions to all poverty problems, Novak made his democratic capitalism unable to incorporate the insight that the human spirit's very accomplishments could also cause society-affecting problems and that climate change as an industrial-capitalist violation of ecological boundedness could be aptly understood this way.

Novak's Niebuhrian irony is amplified by the fact that a base from which to prevent it could have been detected in his own work. First, as Novak wrote in The Spirit of Democratic Capitalism: "All things considered, democratic capitalism will carry a heavy burden to Judgement Day. Its fundamental structure has proved to be productive, its liberties are broad; consequently, its responsibilities are many" (1991a, 358). ${ }^{11}$ Under climate change, Novak could have revitalized this insight about the need for democratic capitalism to accept theological humility and moral responsibility, rather than to lapse into ideological vanity about democratic capitalism's powers and aversion to

11 As Novak (1991a, 350-352) himself noted, democratic capitalism is sinful and cannot be Christian. Besides the core virtues it exhibits, it also tolerates "public immoralities: massage parlors, pornography shops, pickpockets, winos, prostitutes, pushers, punk rock, chambers for group sex—you name it" (Novak 1991a, 350). 
government regulation. However, he persisted in his conservative idealism by maintaining that capitalist wealth and technological knowledge will provide the creative sources for all countries to deal with any environmental issue; hence his blue environmentalism as combined with unwarranted doubt about human-induced climate change. Meanwhile, that, to Novak's delight, many (formerly) poor countries have followed the not unjustly sought Western example by implementing capitalism and making abundant use of fossil fuels has led to the very dangerous state of climate change the world is now in.

Second, as quoted earlier, Novak upheld a view of irony as "a matter of common experience." Carefully considering this Niebuhr-inspired view could have made Novak abandon his conservative idealism and anticipate that even democratic capitalism - which, notwithstanding its merits and Niebuhr's increasing acceptance, is still a creation of human creatures-may well have engendered some unintended serious consequence. Sadly, his self-chosen closed attitude made it virtually impossible for him to accept, let alone assume responsibility for, the climate harm done by West-invented industrial capitalism as a globally spread "gift" rooted in fossil-fuel use for sustained economic growth and welfare. Thus, Novak's pursuing of blue environmentalism and his upholding of climate-change distrust represent a foolish attempt to escape from the need to recognize limits and from the demand for contrition.

In short, Novak displayed "the irony of virtue turning into vice" (Niebuhr 2008,160 ) for overplaying resource-driven democratic capitalism as "gift to the world." He did so by constructing a simplistic, almost ultimate image of a permanently innocent American, and Western, capitalism, a picture that features an overstretch of the human spirit as key factor for welfare, an overconfidence in resources, an overstress on industrial capitalism's economic benefits for the world as a whole, and, as a result, a total neglect of a vast amount of scientifically reliable empirical evidence for human-induced climate change. This image augments the climate insecurity of particularly those one billion poor people living in abysmal environmental conditions who have done nothing to create climate change but suffer most from it; surely this is an ironic outcome, since, as we saw, concern for the poor has been a key impetus to Novak's democratic-capitalist project. Now, Novak's blue environmentalism does have value: earlier we saw him referring to recent inventions such as batteries, nuclear energy, and biofuels - to which we can add that Europe, Japan, and the United States are the world's only regions in which $\mathrm{CO}_{2}$ emission is decreasing now (International Energy Agency 2020). Yet Novak failed to truly consider Niebuhrian temperance as against a limitless economic materialism devoid of humility and modesty; after all, under climate change, little (if any) atmospheric absorptive capacity is left, when 
poor countries still need the "generosity" of fossil energy the most to boost economic growth needed for enhancing human living conditions. Ironically, by ideologically treating it as environmentally supreme, Novak did a serious disservice to his democratic capitalism: he left it behind unequipped with concrete intellectual means to accommodate the challenge of global climate change in a morally responsible way.

\section{5}

\section{Conclusion}

Notwithstanding Novak's self-declared acceptance of Niebuhrian irony and acknowledgment of sinful imperfections in democratic capitalism, Novak's democratic capitalism embodies the key American climate irony due to his persistent devotion to a pivotal yet human-created system of political economy. Novak's climate disbelief is to be understood from, but by no means justified by, his total belief in a generally intervention-free capitalism as for the best possible moral good. Arguably clouded by idealism as well as conservatism, even as regards environmental issues, Novak could not properly see climate change as rooted in something he had explained and defended himself: a well-intentioned large-scale use of fossil fuels, initiated by Anglo-Saxon culture. Rather, by portraying the United States, in his view the most virtuous nation on earth for its democratic-capitalist revolution, as model for the world, Novak made an unrealistic and pretentious claim of American innocence (cf. Niebuhr 2008, 23-25, 34). Possessing Niebuhrian validity, Novak's democratic capitalism was not sought unjustly; yet it fell prey to what Niebuhr saw as the key modern sin: hubris. Novak ignored that the United States should actually recognize its global climate responsibilities for having generated environmental dangers through its resource inventions (cf. Niebuhr 2008, xxiv).

The ironic result of Novak's state of ideological self-imprisonment was that, under anthropogenic climate change, several virtues of his democratic capitalism could turn into vices. Thus, his finding that, due to the cultural-ideational character of fossil resources as effective means for sustained economic growth in a world of poverty, democratic-capitalist America and Europe need not accept the popular cultivation of global resource and climate justice resulted in his total refusal to accept any American climate guilt or responsibility for humaninduced climate change. His emphasis on democratic capitalism's potential for supporting the poor to overcome poverty became eroded by his negligence of capitalism's climate-change implications, which are devastating for people living in poverty, who will not be helped by blue environmentalism when facing rising temperatures and sea levels. 
When he tried to fill the political-economic hole in Niebuhr's thought, Novak should have applied his own support for irony to his democratic capitalism. He could then have understood that, theologically, his view of the human mind as final resource (Novak 2014) was an overstretch of the wisdom of humans, who forget that they are creatures as well as creators and so, unlike God, cannot offer infinite gifts to the world. He could then also have accepted that the United States need not abandon capitalism as such yet should take on its climate responsibility and practice a humble but resolutely generous global leadership in order to nullify its climate irony toward a world of new energy as well as less economic growth. ${ }^{12}$ Finally, Novak could then have become conscious of his own involvement in the climate-ironic situation his democratic capitalism had turned into, and he could subsequently have shown contrition about his conservative idealism while still have insisted on the need for democratic capitalism, albeit a more regulated, greener one (cf. Niebuhr 2008, xxiv).

Having applied Niebuhrian irony in order to arrive at a justifiable — though inevitably subjective - assessment of Novak and his democratic capitalism in the light of anthropogenic climate change, I hope that future Novak research will find ways to moderate his democratic capitalism into a more modest vision that properly dissolves its creator's irony. ${ }^{13}$

\section{References}

Barr, D., and Sabella, J. (2017). The Irony of Environmental History. Political Theology, August 21. https://politicaltheology.com/the-irony-of-environmental-history/.

Beitz, C.R. (1999). Political Theory and International Relations. 2nd ed. Princeton: Princeton University Press.

Blomfield, M. (2019). Global Justice, Natural Resources, and Climate Change. Oxford: Oxford University Press.

Collomb, J.-D. (2014). The Ideology of Climate Change Denial in the United States. European Journal of American Studies 9 (1). https://journals.openedition.org/ ejas/10305.

12 As a Niebuhrian, Novak could have agreed that US climate leadership should be realistically anti-egoist rather than utopianist. As Niebuhr $(2008,36-37)$ wrote: "Every nation must come to terms with the fact that, though the force of collective self-interest is so great, ... national policy must be based upon it; yet also the sensitive conscience recognizes that the moral obligation of the individual transcends his particular community. Loyalty to the community is therefore morally tolerable only if it includes values wider than those of the community."

I thank Simon Polinder and the reviewers for their comments. 
Eberstadt, M. (2019). Catholic All the Way: Michael Novak's Legacy. The Catholic

Thing, March 23. https://www.thecatholicthing.org/2019/03/23/catholic-all-theway-michael-novaks-legacy/.

Garvey, J. (2008). The Ethics of Climate Change. London: Continuum.

Hallegatte, S., Bangalore, M., Bonzanigo, L., Fay, M., Kane, T., Narloch, U., Rozenberg, J., Treguer, D., and Vogt-Schilb, A. (2016). Shockwaves: Managing the Impacts of Climate Change on Poverty. Washington, D.C.: World Bank.

Hausfather, Z., Drake, H.F., Abbott, T., and Schmidt, G.A. (2020). Evaluating the Performance of Past Climate Model Projections. Geophysical Research Letters 47 (1). Hayhoe, K. (2019). I'm a Climate Scientist Who Believes in God: Hear Me Out. New York Times, October 31.

Intergovernmental Panel on Climate Change (1990). Climate Change: The IPCC Scientific Assessment. Cambridge: Cambridge University Press.

Intergovernmental Panel on Climate Change (1995). Second Assessment Climate Change 1995. Geneva: World Meteorological Organization and United Nations Environment Programme.

Intergovernmental Panel on Climate Change (2001). Climate Change 20or: Synthesis Report. Cambridge: Cambridge University Press.

Intergovernmental Panel on Climate Change (2007). Climate Change 2007: Synthesis Report. Geneva: IPCC.

Intergovernmental Panel on Climate Change (2014). Climate Change 2014: Synthesis Report. Geneva: IPCC.

International Energy Agency (2020). Global CO2 Emissions in 2019. IEA, February 11. https://www.iea.org/articles/global-co2-emissions-in-2o19.

Kamminga, M.R. (2018). Reinhold Niebuhr: The Continuing Relevance of His Christian Realism. In: R. Schuett and M. Hollingworth, eds., The Edinburgh Companion to Political Realism, Edinburgh: Edinburgh University Press, pp. 252-264.

Kamminga, M.R. (2019). Westerse klimaatschuld? Een ethische kritiek. Filosofie \& Praktijk 40 (2), pp. 4-20.

Kamminga, M.R. (2020). The Intrinsic Justifiability of Grandfathering in Climate Politics. Etica \& Politica/Ethics \& Politics 22 (3), pp. 751-768.

Landes, D.S. (1998). The Wealth and Poverty of Nations. New York: W.W. Norton.

Lieven, A. (2010). Realism and Progress: Niebuhr's Thought and Contemporary Challenges. In: R. Harries and S. Platten, eds., Reinhold Niebuhr and Contemporary Politics, Oxford: Oxford University Press, pp. 169-182.

Matthews, H.D. (2016). Quantifying Historical Carbon and Climate Debts among Nations. Nature Climate Change 6 (1), pp. 6o-64.

Musyal, S., and Eiermann, M. (2011). We Must Be Opportunistic in the Pursuit of Justice: Conversation with Thomas Pogge. The European, December 14. https:// www.theeuropean.de/en/thomas-pogge--2/6o4o-global-justice. 
Neumayer, E. (2000). In Defence of Historical Accountability for Greenhouse Gas Emissions. Ecological Economics 33 (2), pp. 185-192.

Niebuhr, R. (1932). Moral Man and Immoral Society. New York: Charles Scribner's Sons.

Niebuhr, R. (1941). The Nature and Destiny of Man. Volume 1. London: Nisbet.

Niebuhr, R. (1943). The Nature and Destiny of Man. Volume 2. London: Nisbet.

Niebuhr, R. (1965). Man's Nature and His Communities. New York: Charles Scribner's Sons.

Niebuhr, R. (2008). The Irony of American History. Repr. ed., with a new introduction by Andrew J. Bacevich. Chicago: University of Chicago Press.

Novak, M. (1972). Needing Niebuhr Again. Commentary 54 (3), pp. 52-62.

Novak, M. (1977). New Ironies of American History. Worldview 20 (3), pp. 29-31.

Novak, M. (1986). Reinhold Niebuhr: Model for Neoconservatives. Christian Century 103 (3), pp. 69-71.

Novak, M. (1990). Toward a Theology of the Corporation. 2nd ed. Washington, D.C.: The AEI Press.

Novak, M. (1991a). The Spirit of Democratic Capitalism. 2nd ed. London: The IEA Health and Welfare Unit.

Novak, M. (1991b). Will It Liberate? 2nd ed. Lanham: Madison Books.

Novak, M. (1992). Father of Neoconservatives: Reinhold Niebuhr. National Review 44 (9), pp. 39-42.

Novak, M. (1994). Awakening from Nihilism: The Templeton Prize Address. National Review, April 25. https://www.nationalreview.com/2019/04/ awakening-from-nihilism/.

Novak, M. (2005). Environmentalism Should Not Be a Religion. AEI, January 13. https:// www.aei.org/articles/environmentalism-should-not-be-a-religion/.

Novak, M. (2007). When Greenland was “Green." National Review, May 29. https:// www.nationalreview.com/corner/when-greenland-was-green-michael-novak/.

Novak, M. (2008a). American Energy_and Invention. National Review, May 23. https:// www.nationalreview.com/corner/american-energy-and-invention-michael-novak/.

Novak, M. (2008b). Christmas Atheists. National Review, January 4. https://www. nationalreview.com/2008/o1/christmas-atheists-michael-novak/.

Novak, M. (2009). Mushy Christianity. Catholic Education, February 10. https:// www.catholiceducation.org/en/religion-and-philosophy/apologetics/mushychristianity.html.

Novak, M. (2010). The Liberating Balance. First Things, May 4. https://www.firstthings. com/web-exclusives/2010/o5/the-liberating-balance.

Novak, M. (2013). Writing from Left to Right. New York: Image.

Novak, M. (2014). Three Cardinal Virtues of Business. Lecture held in Vilnius, November 2014. Text version by Holger Lahayne. http://lahayne.lt/2014/12/o3/ michael-novak-in-vilnius-three-cardinal-virtues-of-business/. 
Novak, M. (2015). Blue Environmentalism-Parts 1-3. Patheos, June 24, July 1, July 8. https://www.patheos.com/blogs/michaelnovak/2015/.

Novak, M. (2017). Foreword to Pope Francis and the Caring Society, edited by R.M. Whaples , Oakland: Independent Institute, pp. xix-xxvii.

Novak, M., and Adams, P. (2015). Social Justice Isn't What You Think It Is. New York: Encounter Books.

Pakaluk, C.R. (2017). Michael Novak: A Model for Social Scientists. Public Discourse, November 9. https://www.thepublicdiscourse.com/2017/11/20301/.

Pogge, T.W. (2008). World Poverty and Human Rights. 2nd ed. Cambridge: Polity Press.

Powell, J. (2019). Scientists Reach 100\% Consensus on Anthropogenic Global Warming. Bulletin of Science, Technology \& Society 37 (4), pp. 183-184.

Rawls, J. (1999). The Law of Peoples. Cambridge: Harvard University Press.

Rice, D.F. (2015). The Fiction of Reinhold Niebuhr as a Political Conservative. Soundings 98 (1), pp. $59-83$.

Steinfels, P. (2017). A Turn That Went a Long Way: Remembering Michael Novak. Commonweal, February 27. https:/www.commonwealmagazine.org/ turn-went-long-way. 